Article

\title{
In Vitro Corrosion of Titanium Nitride and Oxynitride-Based Biocompatible Coatings Deposited on Stainless Steel
}

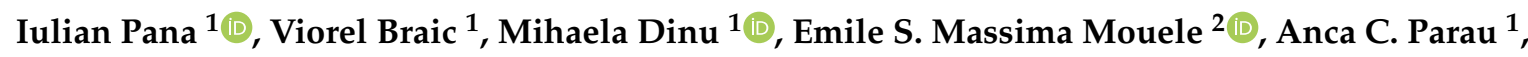 \\ Leslie F. Petrik ${ }^{2}$ (D) and Mariana Braic $1, *$ (D) \\ 1 National Institute of Research and Development for Optoelectronics-INOE 2000, 409 Atomistilor St., \\ 077125 Magurele, Romania; iulian.pana@inoe.ro (I.P.); viorel.braic@inoe.ro (V.B.); \\ mihaela.dinu@inoe.ro (M.D.); anca.parau@inoe.ro (A.C.P.) \\ 2 Environmental and Nano Sciences, Department of Chemistry, University of the Western Cape, \\ Robert Sobukwe Road, Bellville 7535, South Africa; 2916096@myuwc.ac.za (E.S.M.M.); \\ lpetrik@uwc.ac.za (L.F.P.) \\ * Correspondence: mariana.braic@inoe.ro; Tel.: +40-0214-575-759
}

Received: 23 June 2020; Accepted: 20 July 2020; Published: 22 July 2020

\begin{abstract}
The reactive cathodic arc deposition technique was used to produce Ti nitride and oxynitride coatings on 304 stainless steel substrates (SS). Both mono (SS/TiN, SS/TiNO) and bilayer coatings (SS/TiN/TiNO and SS/TiNO/TiN) were investigated in terms of elemental and phase composition, microstructure, grain size, morphology, and roughness. The corrosion behavior in a solution consisting of $0.10 \mathrm{M} \mathrm{NaCl}+1.96 \mathrm{M} \mathrm{H}_{2} \mathrm{O}_{2}$ was evaluated, aiming for biomedical applications. The results showed that the coatings were compact, homogeneously deposited on the substrate, and displaying rough surfaces. The XRD analysis indicated that both mono and bilayer coatings showed only cubic phases with (111) and (222) preferred orientations. The highest crystallinity was shown by the SS/TiN coating, as indicated also by the largest grain size of $23.8 \mathrm{~nm}$, which progressively decreased to $16.3 \mathrm{~nm}$ for the SS/TiNO monolayer. The oxynitride layers exhibited the best in vitro corrosion resistance either as a monolayer or as a top layer in the bilayer structure, making them a good candidate for implant applications.
\end{abstract}

Keywords: titanium nitride and oxynitride; reactive cathodic arc deposition; mono and bilayer coatings; coating adhesion; corrosion resistance

\section{Introduction}

As largely reported in the literature, stainless steels are the best corrosion-resistant alloys; however, their exposure to chemical demanding environments may produce and accelerate their corrosion. Consequently, the effects of different parameters related to their composition and the specific corrosive environments have been investigated [1-5]. The presence of $\mathrm{Cr}, \mathrm{Ni}, \mathrm{Mo}$, and $\mathrm{Cu}$ in the composition of different stainless steel alloys has a positive role due to the ability of these elements to form superficial passive layers of oxides in corrosive environments, which limit the propagation of the corrosion process. In the case of long-term exposure to corrosive environments, the protective passive layer becomes unstable and spontaneously decays, such as the metal rusting due to oxidation becomes evident, being also accompanied by the weight loss. After the passive layer is damaged/broken, the corrosion process of stainless steel is accelerated [3,4], and its corrosion will proceed, depending on the type of corrosive environment and duration of the corrosive attack. The acidic media produce an enhanced corrosion attack, such that in order to reduce the corrosion risk, one should carefully select the grade of stainless steel and use a less acidic medium [6]. As the rate of the corrosive reactions is temperature 
dependent, the corrosive environment temperature is an important factor, as well as the contact duration [6]. Moreover, due to their pronounced chemical activity, the concentration of halogens in the corrosion media should be minimized. Apart from these precautions, the use of a low carbon grade (C wt. $\%<0.03 \%$ ) is also recommended [1,6]. Austenitic stainless steel 304 (SS) is considered as one of the most suitable materials for the manufacturing of medical devices and various implants used as cardio stents, orthopedic, and dental (nuts and screws) implants, valued for its malleability and resistance to corrosion, being frequently the preferred choice because it offers unique characteristics at an economical price $[7,8]$. There are reported different strategies for the surface modification of 304 stainless steel, mainly for their corrosion resistance and mechanical properties improvement, such as plasma nitriding [9], hard chromium coatings obtained by electroplating, followed by their plasma nitridation [10], ultrasonic impact treatment [11], or increased wettability by picosecond laser surface microstructuring [12].

The continuous increase of the demands related to materials' biocompatibility generates the need for improved corrosion resistance and biocompatibility of the materials. Transition metals, mostly the low-valent, early ones, exhibit properties suitable for many industrial applications due to their particular chemical properties, derived from their specific electronic configurations [13]. Presently, different high-performance titanium alloys are accepted, and some of them are widely used as biomedical metals [14-17]. Transition metal-based alloys have also been widely used, mainly in the biomedical sector targeting implant or medical instruments $[18,19]$, but their cost is, in most cases, prohibitive. A different and economically efficient way for the corrosion resistance enhancement of stainless steel made components is their coating using compounds with superior resistance to chemical attacks in various harsh media [20-24]. The coatings selection should consider the composition of the selected stainless steel alloy, of the candidate coating, and of the corrosive environment, as well as the temperature of the environment during the corrosive attack.

In order to tackle the issues related to the coating selection, various coating materials have been investigated. To begin with, nitride-based compounds, such as TiN, $\mathrm{ZrN}, \mathrm{CrN}$, and TiAlN, have been suggested as hard coatings for surface modification, surface barriers, or electrodes [25-30] ]. In order to combine superior mechanical properties, e.g., hardness and adhesion to the substrate, with enhanced corrosion resistance, new compounds, such as oxynitrides, of the transitional metals with low oxygen content have been developed [31-35] due to their superior chemical stability, notable optical, electronic, and mechanical properties [36-38], with superior mechanical properties compared to those reported for the oxides [39-42]. The interest in titanium oxynitride films is due to the pronounced dependence of the oxynitrides properties on the N/O ratio [33,34,43-47]. Titanium oxynitride coatings have been reported to have a large variety of applications, depending on the N/O ratio, presenting a wide variety of properties, such as biocompatibility [34,46,48], wear and corrosion resistance [33,38,49], being used as photocatalytic coatings [50,51], plasmonic material for nanophotonics [47], or solar selective absorbers [52], just to name a few. However, the variation of environmental factors, such as concentration, $\mathrm{pH}$, oxidizing environment, temperature, and pressure, may disrupt their stability and hence may lead to undesired reactions [53].

Titanium oxynitrides, with different oxygen contents, present properties, which are superior to either titanium nitrides or titanium oxides [54]. In particular, titanium oxynitrides are widely used in medicine and in chemical industries because of the excellent combination of chemical and mechanical properties $[38,55]$. To our knowledge, till now, there is only one reference about titanium oxynitride coatings produced by cathodic arc evaporation, which compares the wettability of the coatings deposited either by cathodic arc evaporation or by magnetron sputtering [56]. Thus, we anticipate that the titanium nitride and the isostructural titanium oxynitride, with low oxygen content (TiNO), can assist in achieving low-cost and efficient bilayer, which preserves the superior properties of the component layers in relation to the adhesion to the substrate and the corrosion resistance.

In the present work, we focused on Ti nitride and oxynitride coatings as possible candidates for corrosion improvement of polyvalent 304 stainless steel (SS), aimed for use as biomedical materials. 
Based on the superior anticorrosive properties of TiN, we also investigated the corrosion resistance of TiNO coatings, as the oxygen content determines more proficient the creation of passive layers under the saline solution corrosive attack [49]. To prove the aforementioned expectation on the two isostructural coatings, we studied two bilayer structures composed of TiNO and TiN layers, considering the superior properties of bilayer structures [32,57-61], in order to find the best solution for our goal, obtaining coatings adherent to SS substrate with superior resistance to corrosion [14].

The corrosion performance of the coated SS in corrosive solution was assessed by the potentiodynamic polarization technique and was correlated with the elemental and phase composition and surface morphology. The corrosion resistance tests were performed in $\mathrm{H}_{2} \mathrm{O}_{2}$ augmented saline solution $\left(0.1 \mathrm{M} \mathrm{NaCl}+6 \% \mathrm{H}_{2} \mathrm{O}_{2}, \mathrm{pH}=4\right)$, which was selected because it might simulate different corrosive media in biomedical applications. It is known that the most biological environments consist of $\mathrm{NaCl}$ with different concentrations (saliva $=0.4 \mathrm{~g} / \mathrm{L}$; simulated body fluid $=8.035 \mathrm{~g} / \mathrm{L}$; Hank solution $=8 \mathrm{~g} / \mathrm{L} ;$ Ringer solution $=8.6 \mathrm{~g} / \mathrm{L} ; \mathrm{DMEM}=6.4 \mathrm{~g} / \mathrm{L}$ ). The addition of the $\mathrm{H}_{2} \mathrm{O}_{2}$ oxidizing agent to the saline solution is motivated because it is produced in vivo by different mechanisms [62], because a large number or even all human cells are exposed to certain levels of hydrogen peroxide [63]. Therefore, the addition of hydrogen peroxide to the saline solution was used to mimic the enhanced corrosion environment in both cases. It should be noted that in the presence of $\mathrm{H}_{2} \mathrm{O}_{2}$ and $\mathrm{Cl}^{-}$, there is an enhanced corrosion attack, causing more damage due to the appearance of the intergranular stress corrosion cracking in austenitic steel under tensile stress [64-66].

The properties of coatings used in implant applications, aiming at shielding the metallic parts from the action of the aggressive oral environment, are of great interest and will be further investigated, particularly their corrosion resistance. The potentiodynamic polarization is one of the most frequently utilized electrochemical methods for resistance corrosion assessment. The technique uses a wide potential range, which is applied to the test electrode. Depending on the increase or the decrease of the polarization potential, oxidation or reduction reactions take place on the tested surface, such that a certain current is generated for each potential value, yielding a polarization curve, from which the corrosion potential and the corrosion current density can be obtained. The main advantage of this method is its ease in detecting localized corrosion and ascertaining the corrosion protection efficiency. In this study, the potentiodynamic polarization technique was used to assess the protective performance of TiN and TiNO-based films used as bio-coatings for 304 SS, aiming for implant applications.

\section{Materials and Methods}

\subsection{Coating and Specimens}

The TiN and TiNO coatings, as mono and bilayer, were deposited on $304 \mathrm{SS}$ solid discs $(\Phi=20 \mathrm{~mm}$, $2 \mathrm{~mm}$ thick) by the cathodic arc evaporation technique (CAE), using a Ti cathode in nitrogen plasma (TiN) or nitrogen and oxygen plasma (TiNO). Bare 304 SS discs were used as a reference. 304 SS was chosen because it is essentially non-magnetic in the annealed condition and is ductile and soft if not hardened by cold working. Due to its lower carbon content compared with other stainless steels, it exhibits better corrosion resistance.

The composition of 304 SS discs, expressed in wt.\%, provided by the manufacturer (Bibus Metals SRL) is: $\mathrm{Fe}=70.976 \%, \mathrm{Cr}=17.746 \%, \mathrm{Ni}=8.524 \%, \mathrm{Mn}=1.22 \%, \mathrm{Mo}=0.589 \%, \mathrm{Cu}=0.539 \%, \mathrm{Si}=0.208 \%$, $\mathrm{Co}=0.160 \%, \mathrm{P}=0.020 \%, \mathrm{~S}=0.014 \%$, and $\mathrm{C}=0.004 \%$. The $304 \mathrm{SS}$ discs were polished with abrasive paper from 80 to 800 mesh size, up to a roughness $\left(R_{\mathrm{a}}\right)$ of $50 \mathrm{~nm}$.

For coatings deposition, a Ti cathode (99.5\% purity, Cathay Advanced Materials Ltd., Guangzhou, China) was used. In order to control the uniformity of coatings, during the deposition, a rotating sample holder ( $5 \mathrm{rpm}$ ) was used. Prior to the deposition, all samples were sputter etched with $1 \mathrm{keV}$ $\mathrm{Ar}^{+}$for $10 \mathrm{~min}$. The deposition parameters were as follows: residual pressure $=5 \times 10^{-4} \mathrm{~Pa}$; total gas pressure during deposition $=8 \times 10^{-2} \mathrm{~Pa} ; \mathrm{N}_{2}$ flow rate $=60 \mathrm{sccm} ; \mathrm{O}_{2}$ flow rate $=17 \mathrm{sccm}$; arc current $=90 \mathrm{~A}$; substrate bias voltage $=-200 \mathrm{~V}$; temperature $=200^{\circ} \mathrm{C}$. For the bilayers, after each layer, 
the voltage sources were turned off, the deposition chamber was pumped off, and then the required gas or gas combination was released in the chamber till the deposition pressure point, and the deposition process was continued.

All the deposition parameters were selected in order to obtain stoichiometric coatings (ratio non-metal/metal $\sim 1$ ). The value of bias voltage was carefully chosen based on our previous experiments [67], which showed that this value is the best for preparing dense Ti-based coatings with good mechanical and corrosion behavior. The substrate temperature, measured by a backside non-contact thermocouple, was selected for getting a superior adhesion of the coatings to the substrates $[67,68]$. The deposition conditions for the bilayers were the same as for monolayers, except for the deposition duration of each layer of the bilayer, and diminished in order to get a similar thickness of the mono and bilayer coatings $(\approx 1 \mu \mathrm{m})$.

\subsection{Characterization of Coatings}

A scanning electron microscope (SEM) (Hitachi TM3030 Plus, Tokyo, Japan) with an energy-dispersive X-ray spectrometer (EDS, Bruker, Billerica, MA, USA) was used for assessing the elemental composition and the morphology of the coatings. Surface morphology was also investigated by atomic force microscopy (AFM, INNOVA, Bruker, Billerica, MA, USA) operated in the tapping mode, over an area of $10 \times 10 \mu \mathrm{m}^{2}$.

$\mathrm{X}$-ray diffraction method (XRD) was used to determine the phase composition, texture, and grain size of the coatings (SmartLab diffractometer, Rigaku, Tokyo, Japan), with $\mathrm{CuK} \alpha$ radiation $(\lambda=0.15405 \mathrm{~nm})$. The measurements were taken from $20^{\circ}$ to $100^{\circ}$, at a step size of $0.02^{\circ}$.

The thickness and roughness of the coatings were investigated using a surface profilometer (Dektak 150, Bruker, Billerica, MA, USA) equipped with a $2.5 \mu \mathrm{m}$ diameter stylus. The roughness was measured on a length of $10 \mathrm{~mm}$, and the two main parameters were calculated: arithmetic average deviation from the mean line $\left(R_{\mathrm{a}}\right)$ and root mean square average of the profile heights over the evaluation length $\left(R_{\mathrm{q}}\right)$.

The adhesion of coatings to the SS substrate was determined by scratch tests, which were carried out using the UMT-TriboLab platform (Bruker, Madison, WI, USA), utilizing a $0.2 \mathrm{~mm}$ radius diamond tip as indenter. The load was continuously increased from 0 to $100 \mathrm{~N}$, the scratching speed was $10 \mathrm{~mm} / \mathrm{min}$, and the scratching distance was $10 \mathrm{~mm}$, according to EN 1071-3/2005 standard) [69]. An optical microscope and an acoustic sensor (EN 1071-3/2005 standard) were used to determine the critical load $\left(L_{c}\right)$, at which failure of the coating took place.

The corrosion protective properties were assessed by the Tafel technique using a Versa Stat 3 Potentiostat/Galvanostat. The electrolyte consisted of $0.10 \mathrm{M} \mathrm{NaCl}+1.96 \mathrm{M} \mathrm{H}_{2} \mathrm{O}_{2}$ solution with $\mathrm{pH}=4$. All the tests were performed at $37 \pm 0.5{ }^{\circ} \mathrm{C}$. A Pt counter electrode and an $\mathrm{Ag} / \mathrm{AgCl}$ reference electrode were used. The samples were used as a working electrode, being placed in a Teflon holder for providing a working area of $1 \mathrm{~cm}^{2}$. The open-circuit potential $\left(E_{\mathrm{OC}}\right)$ was monitored for $15 \mathrm{~h}$ after immersion in the electrolyte. Further, Tafel plots were recorded from -0.25 to $0.25 \mathrm{~V}$ vs. $\mathrm{E}_{\mathrm{OC}}$ with a scanning rate of $1 \mathrm{mV} / \mathrm{s}$. The test conditions were selected in good agreement with those recommended in the ASTM C1624-05 (2015) standard [70]. The corrosion potential $\left(E_{\mathrm{corr}}\right)$, anodic $\left(b_{\mathrm{a}}\right)$ and cathodic $\left(b_{\mathrm{c}}\right)$ slopes, and the corrosion current density $\left(i_{\text {corr }}\right)$ were extracted from the Tafel curves. These parameters were added in the Stern-Geary equation [71] for calculating the polarization resistance $\left(R_{\mathrm{p}}\right)$ :

$$
R_{p}=\frac{1}{2.3 i_{\text {corr }}}\left\lfloor\frac{b_{a} b_{c}}{b_{a}+b_{c}}\right\rfloor
$$

Moreover, the coating's porosity $(P)$ was estimated from Elsener's empirical equation [72,73]:

$$
P=\left(\frac{R_{\mathrm{p} \text { substrate }}}{R_{\mathrm{p} \text { coating }}}\right) \cdot 10^{\frac{-\left|\Delta E_{\text {corr }}\right|}{b_{\mathrm{a}}}}
$$


The protective efficiency $\left(P_{\mathrm{e}}\right)$ was also calculated based on the formula reported in Refs. [73,74], considering the ion corrosion densities of the substrate $\left(i_{\text {corr-substrate }}\right)$ and coating $\left(i_{\text {corr_coating }}\right)$ :

$$
P \mathrm{e}=\left(1-\frac{i_{\text {corr_coating }}}{i_{\text {corr_substrate }}}\right)
$$

\section{Results and Discussions}

\subsection{Elemental Composition}

The elemental compositions of the coatings deposited on SS solid discs are shown in Table 1. One can notice that the presence of Ti concentration was almost constant in all coatings (around 49 at.\%). In the oxynitride monolayer, the oxygen concentration was higher than in the SS/TiN/TiNO bilayer, as expected due to the reduced thickness of the oxynitride in the bilayer. In the SS/TiNO/TiN bilayer, the concentration of oxygen was very low $(1.2$ at.\%) due to the signal absorption in the $\sim 500 \mathrm{~nm}$ thick $\mathrm{SS} / \mathrm{TiN}$ layer. Based on the calculated $(\mathrm{O}+\mathrm{N}) / \mathrm{Ti}$ ratios, the deposited coatings were stoichiometric, as intended.

Table 1. The elemental composition of the investigated specimens before the corrosion test.

\begin{tabular}{ccccc}
\hline \multirow{2}{*}{ Substrate/Coating } & \multicolumn{2}{c}{ Elemental Composition (at.\%) } & \multirow{2}{*}{$(\mathbf{O}+\mathbf{N}) / \mathbf{T i}$} \\
\cline { 2 - 4 } & $\mathbf{T i}$ & $\mathbf{N}$ & $\mathbf{O}$ & \\
\hline SS /TiN & $49.6 \pm 1.2$ & $50.4 \pm 1.3$ & - & $1.00 \pm 0.05$ \\
SS /TiNO & $49.7 \pm 1.3$ & $43.0 \pm 1.0$ & $7.3 \pm 0.2$ & $0.98 \pm 0.08$ \\
SS /TiN/TiNO & $49.4 \pm 1.3$ & $44.9 \pm 1.2$ & $5.7 \pm 0.2$ & $1.03 \pm 0.08$ \\
SS /TiNO/TiN & $49.3 \pm 1.3$ & $49.5 \pm 1.3$ & $1.2 \pm 0.1$ & $1.03 \pm 0.09$ \\
\hline
\end{tabular}

\subsection{Phase Composition and Grain Size}

The XRD diffraction patterns, presented in Figure 1, showed only TiN phases with cubic structure and (111) and (222) preferred orientations (indexed according to JCPDS no. 04-017-6803) [75]. Moreover, the peaks corresponding to the substrate were also identified. The (111) peak in TiN monolayer was observed at $36.24^{\circ}$ due to the compressive stress developed during growth in transition metal nitride and carbide coatings obtained by cathodic arc evaporation [57,72]. A small shift towards higher angles, at $36.32^{\circ}$, was evidenced for the main (111) peak in SS/TiNO, indicating the lattice constant decrease due to its deformation upon oxygen incorporation, suggesting the formation of a single-phase cubic solid solution for the TiNO structure. The conclusion was supported by the almost unity value of $(\mathrm{N}+\mathrm{O}) /$ Ti ratio obtained by EDS (Table 1). The (111) maximum observed in SS/TiNO/TiN diffractogram, at $36.26^{\circ}$, was the result of the compressive stress in the bilayer and of the contribution of the deformed TiNO lattice. The same shift to a higher value compared to TiN and lower than the one in TiNO was observed at $36.30^{\circ}$ in SS/TiN/TiNO films.

The deformation of the TiN structure, due to oxygen incorporation, increased the number of defects, facilitating the amorphization, resulting in a decrease of the grain size value in TiNO coatings.

The average crystallite size of the mono and bilayer coatings was calculated from the XRD pattern, according to the highest intensity peak corresponding to the (111) plane, using Debye-Scherrer Equation [76]: $d=\mathrm{k} \lambda / \beta \cdot \cos \theta$, where $d$ is the crystallite size, $\lambda$ is X-ray wavelength $(1.54178 \AA, \theta$ is the diffraction angle, and $\beta$ is full width at half maximum (FWHM). The best crystallinity was exhibited by the SS/TiN coating, as indicated by the largest grain size, while SS/TiNO monolayer exhibited the smallest grain size $(d=16.3 \mathrm{~nm})$. Table 2 presents the calculated value of the grain size for all deposited coatings, but we should mention that the bilayer values are just indicative because they combine the grain size values from each individual layer. The formation of an amorphous phase of Ti suboxides cannot be excluded, but no Ti oxide phases were observed in the diffractograms [77,78]. However, the small amount of oxygen determined from the EDS analysis and the decrease of the grain size might be concurrent with the formation of an amorphous Ti oxide phase. 


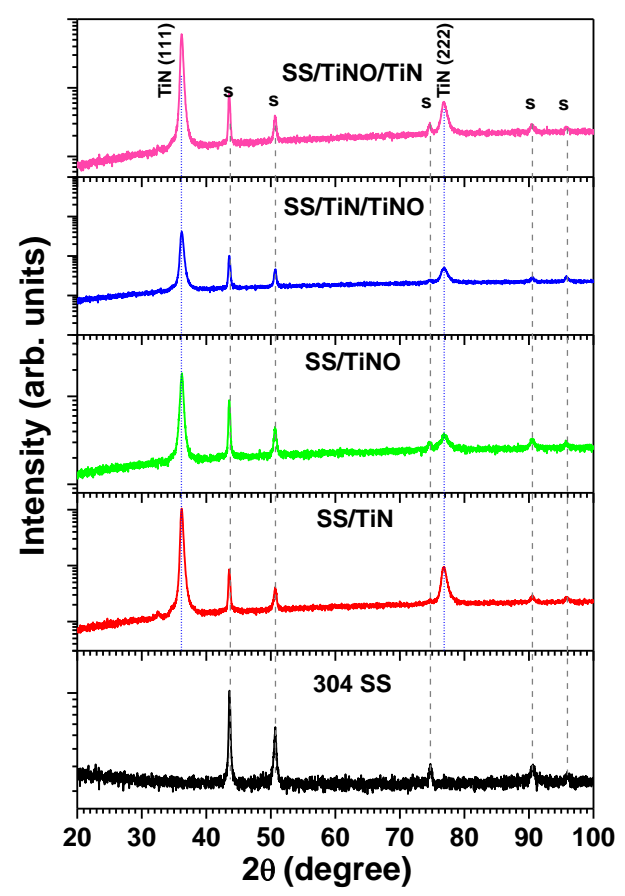

Figure 1. XRD diffraction patterns of investigated samples.

For the bilayers (SS/TiN/TiNO and SS/TiNO/TiN), one can observe that the position of (111) maxima and the calculated grain size values were closely matching the specific values obtained for the TiNO and TiN monolayers, respectively.

Table 2. Grain size $(d)$ of the coatings.

\begin{tabular}{lc}
\hline Coating & $\boldsymbol{d}$ (nm) \\
\hline SS/TiN & 23.8 \\
SS/TiNO & 16.3 \\
SS/TiN/TiNO & 19.9 \\
SS/TiNO/TiN & 22.1 \\
\hline
\end{tabular}

\subsection{Coating Roughness and Adhesion to the Substrate}

Considering the initial $R_{\mathrm{a}}$ roughness of the substrates $(50 \mathrm{~nm})$, the coating roughness values increased with a factor spanning from 5.8 (SS/TiNO) to 8.3 (SS/TiN) (Figure 2). The roughness values of both types of bilayer were between those of monolayers. The SS/TiNO monolayer exhibited the lowest $R_{\mathrm{a}}$ value $\left(R_{\mathrm{a}} \sim 290 \mathrm{~nm}\right)$, while that of SS/TiN was the highest $\left(R_{\mathrm{a}} \sim 420 \mathrm{~nm}\right)$, indicating that the addition of oxygen generated a significant decrease in the surface roughness, due to coating amorphization, as revealed by the decreased grain size values (Table 2). The $R_{a}$ roughness of the SS/TiN/TiNO bilayer was close to that of SS/TiNO monolayer, while for the SS/TiNO/TiN bilayer, the value was a bit lower but close to that of SS/TiN. Considering the $R_{\mathrm{q}}$ parameter, the values presented the same trend as those of the $R_{\mathrm{a}}$ parameter.

In the implants, the surface roughness represents an important parameter, as it determines the interaction of the cells in the proxy area, being crucial in the process of bone formation. Despite the fact that epithelial cells and fibroblasts bond better on smooth surfaces, the cathodic arc produced coatings, with roughness values around $500 \mathrm{~nm}$ (Figure 2a,b), might induce increased adhesion of human osteoblast cells because the rough surfaces were reported to enhance the adhesion and differentiation of the osteoblasts and to stimulate the bone growth [79-82].

The scratch adhesion tests (Figure 2c) revealed that the TiN monolayer presented a higher adhesion to the substrate compared to the TiNO monolayer, which was expected due to the coating 
amorphization, as previously reported for amorphous films [42]. However, the bilayers that had a certain layer at the substrate interface were found to exhibit better adhesion strength than the corresponding monolayer. The increased adhesion of the bilayers to the substrate might be due to interfacial bonding effects $[83,84]$, and the result of their iso-structural crystallography, which permits the interdiffusion of the layers, and which is well documented in the literature $[85,86]$.

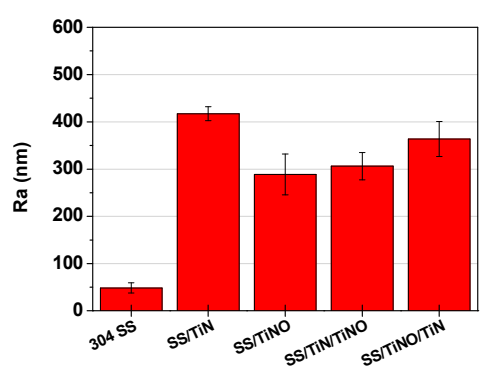

(a)

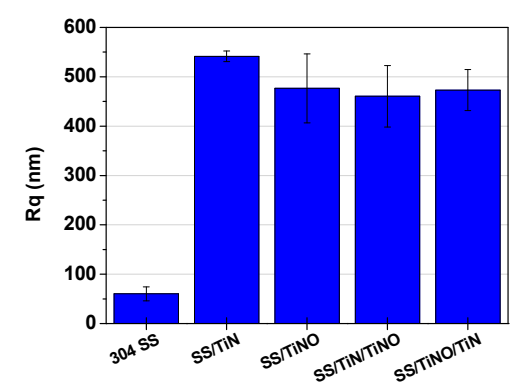

(b)

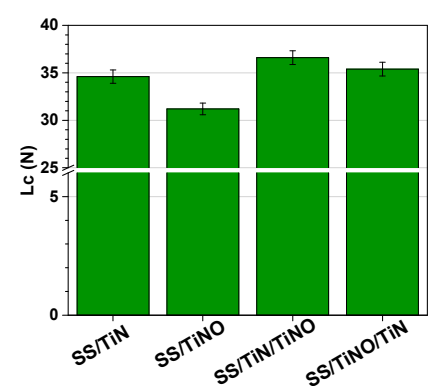

(c)

Figure 2. Roughness parameters and coatings adhesion: (a) $R_{\mathrm{a}}$-arithmetic average deviation from the mean line ( $\mathrm{Ra}$ ); (b) $R_{\mathrm{q}}$-the root mean square average of the profile heights over the evaluation length; (c) $L_{\mathrm{c}}$-critical load, at which failure of the coating took place.

Figure 3a,b present the SEM and AFM images of monolayers. As expected for the CAE deposited coatings, the surfaces of both monolayers were covered by some microdroplets of different diameters, as already ascertained by the surface profilometry measurements and shown in Figure 2. Higher droplet density, with larger diameters, was observed on the TiN surface compared to TiNO. Despite the presence of droplets, both coatings were uniformly deposited, without any major defects, such as pinholes, voids, or cracks.

On the surface of the TiN monolayer, particles were agglomerated, resulting in high peaks. This peculiarity of the CAE deposition was due to the arc discharge, which generates a dense plasma that locally melts the cathode surface, generating droplet deposition on the growing film. These droplets are seen in Figure $3 \mathrm{a}$ as white spots because edge features are sources of enhanced electron emission, generating higher electron currents measured by the EDS detector. The presence of the droplets was clearly evident in the AFM images (Figure 3b). However, because SEM and AFM images were acquired on different systems, the SEM and AFM images were showing different areas on the same coating, thus there was no direct correlation between the white spots in Figure $3 \mathrm{a}$ and the protruding features with sharp edges clearly shown in Figure $3 \mathrm{~b}$. The number and volume of the droplets might be correlated to the melting temperatures $\left(T_{\mathrm{m}}\right)$ of the reaction products formed on the cathode surface during the reactive deposition (TiN, TiO): $T_{\mathrm{m}}{ }^{\mathrm{TiN}}\left(2950^{\circ} \mathrm{C}\right)>T_{\mathrm{m}}{ }^{\mathrm{TiO}}\left(1750^{\circ} \mathrm{C}\right.$ [87]. Even if the deposited monolayer coating consisted mainly of TiN or TiNO (preserving the rock-salt cubic structure of TiN in which oxygen atoms entered interstitial or as $\mathrm{N}$ substitutes), due to the lower $T_{\mathrm{m}}{ }^{\mathrm{TiO}}$ value, the $\mathrm{TiO}$ islands on the cathode surface were frequently ejected as smaller microdroplets. On the contrary, the TiN compound was ejected less frequently, thus large microdroplets were formed on the TiN coatings surface, as evidenced by the AFM measurement and shown in Figure 3b. 


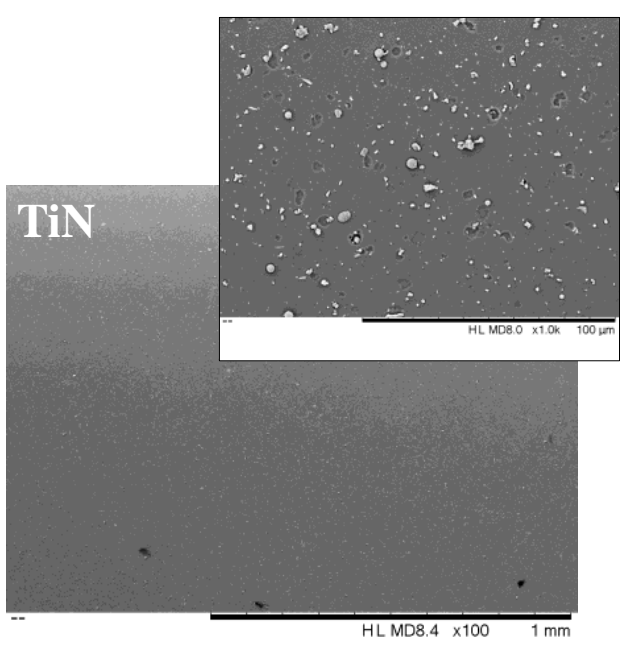

(a)

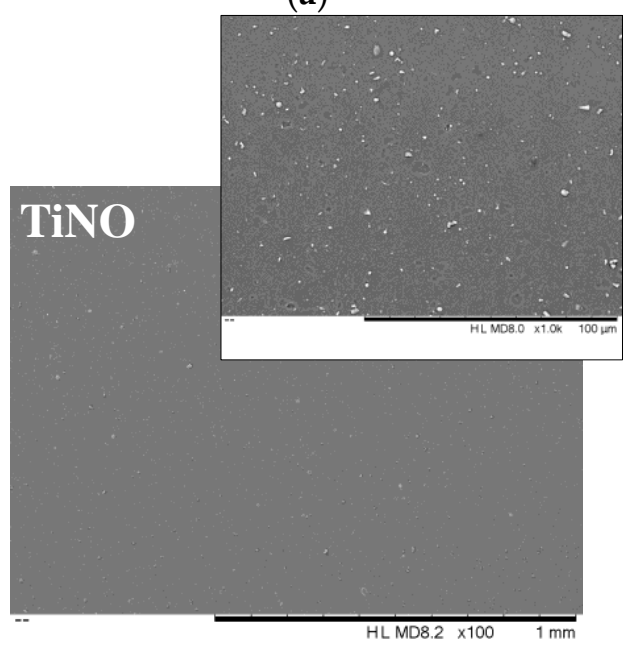

(b)

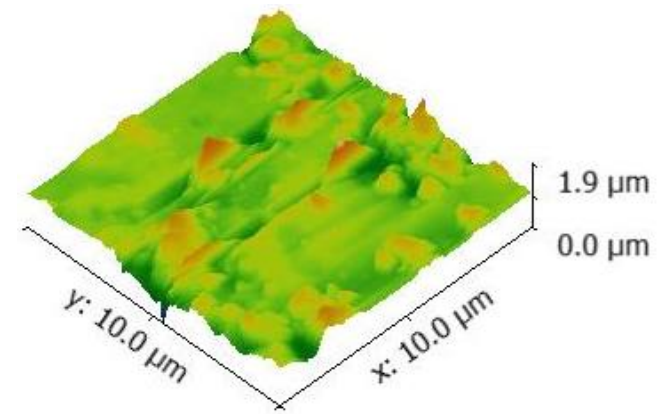

(c)

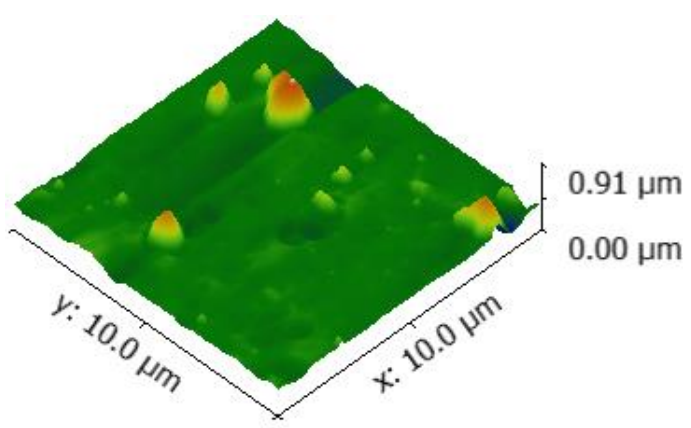

(d)

Figure 3. Surface morphology. (a) SEM image of TiN coating; (b) SEM image of TiNO coating; (c) AFM image of TiN coating; (d) AFM image of TiNO coating.

\subsection{In Vitro Corrosion Tests}

The corrosive media can significantly affect the integrity of metallic surfaces exploited in many applications. Thus, it is important for many materials manufacturers and designers to investigate the effect of a corrosive environment on the material properties, for a better selection of the material to be used in the specific corrosive environment required by various applications. The surface of any metal is covered by an oxide layer when it comes in contact with oxygen from the atmosphere or wet/liquid environments (e.g., saline media, marine environment). Because this oxide layer offers anti-corrosion protection, it is important to find nobility of the surface, which denotes the surface tendency to chemically convert into a stable oxidized state. In laboratory investigation, this nobility can be analyzed by measuring the open circuit potential $\left(\mathrm{E}_{\mathrm{oc}}\right)$. Figure 4 presents the evolution of $\mathrm{E}_{\mathrm{oc}}$ during the $15 \mathrm{~h}$ immersion of the studied coatings in $0.10 \mathrm{M} \mathrm{NaCl}+1.96 \mathrm{M} \mathrm{H}_{2} \mathrm{O}_{2}$ solution $\mathrm{t} 37 \pm 0.5^{\circ} \mathrm{C}$. From the beginning of the test, $\mathrm{E}_{\mathrm{oc}}$ potential of the uncoated SS substrate started to decrease, being stabilized after about $5 \mathrm{~h}$ of immersion. This result indicated that the oxide layer formed on its surface was unstable and was easily destroyed. All coated samples reached a steady state after about $1.5 \mathrm{~h}$ of immersion at around $0.2 \mathrm{~V}$, indicating the formation of a stable passive layer at the surface. All coatings presented more electropositive $E_{o c}$ potential values than the bare substrate, their values spanning a 
small interval. The most electropositive $\mathrm{E}_{\mathrm{oc}}$ potential was found for the SS/TiN/TiNO bilayer, meaning that this surface was nobler than others. Note that the mono or bilayer coatings containing TiNO exhibited the most electropositive $\mathrm{E}_{\mathrm{oc}}$ potential, compared with the other two coatings, with the TiN layer facing the electrolyte.

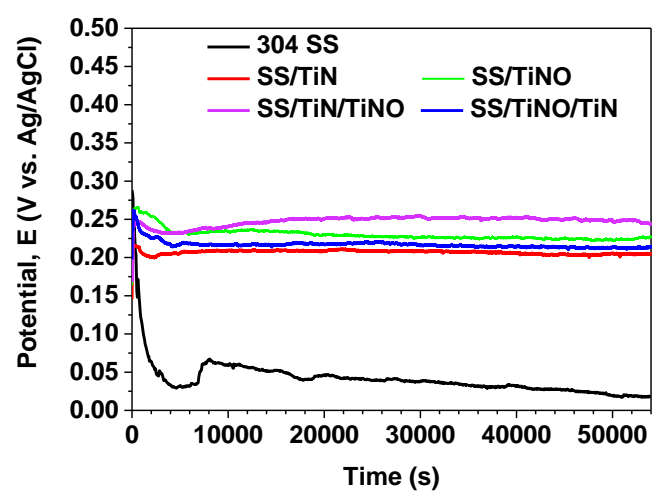

Figure 4. Open circuit potential $\left(\mathrm{E}_{\mathrm{oc}}\right)$ evolution during the $15 \mathrm{~h}$ immersion in $0.10 \mathrm{M} \mathrm{NaCl}+1.96 \mathrm{M}$ $\mathrm{H}_{2} \mathrm{O}_{2}$ at $37 \pm 0.5^{\circ} \mathrm{C}$.

Figure 5 presents the Tafel curves of the coated and bare substrates. Table 3 shows the corrosion potential $\left(\mathrm{E}_{\mathrm{corr}}\right)$ and the corrosion current density $\left(\mathrm{i}_{\mathrm{corr}}\right)$ values extracted from Tafel plots. The most electropositive corrosion potential was displayed by the TiNO monolayer, followed by SS/TiN/TiNO bilayer, SS/TiNO/TiN bilayer, TiN monolayer, and bare substrate. As known, the corrosion rate of a coating is directly proportional to the $i_{\text {corr }}$ value [88], and a low $E_{\text {corr }}$ value indicates an augmented thermodynamic tendency of the material to corrode [89]. Consequently, lower $i_{\text {corr }}$ values and increased positive $\mathrm{E}_{\mathrm{corr}}$ values represent a clear indication of better corrosion resistance [90,91]. As known, the grain boundary and voids can modify the kinetics of hydrogen evolution during the electrochemical process [92]. Because hydrogen is a reversible trap at different points of dislocations, such as voids, this might be a reason for the shift to more positive values of the measured $\mathrm{E}_{\mathrm{corr}}$, for the coatings with smaller grain size values [93]. All the coated surfaces showed decreased $i_{\text {corr }}$ values together with a shift in the positive direction in the $\mathrm{E}_{\mathrm{corr}}$, indicating the decrease in the corrosion rate $[94,95]$ compared with the uncoated substrate.

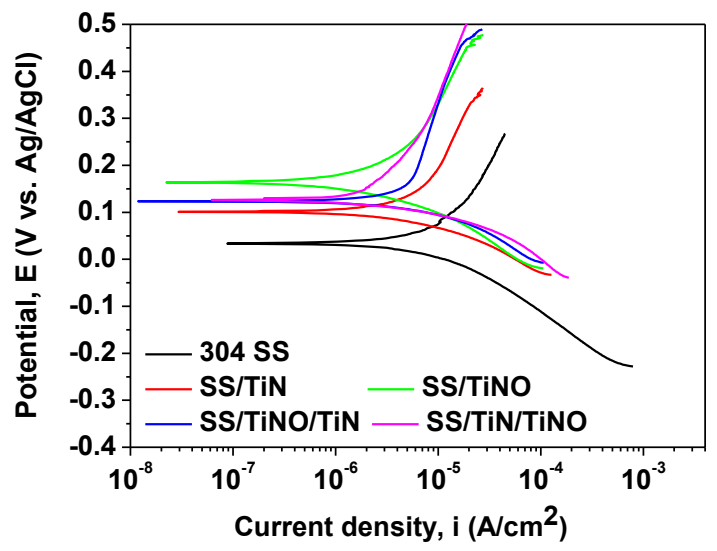

Figure 5. Potentiodynamic curves of studied samples in $0.10 \mathrm{M} \mathrm{NaCl}+1.96 \mathrm{M} \mathrm{H}_{2} \mathrm{O}_{2}$ at $37 \pm 0.5^{\circ} \mathrm{C}$. 
Table 3. Corrosion parameters of studied samples in $0.10 \mathrm{M} \mathrm{NaCl}+1.96 \mathrm{M} \mathrm{H}_{2} \mathrm{O}_{2}$ at $37 \pm 0.5{ }^{\circ} \mathrm{C}$ : $\mathrm{E}_{\mathrm{OC}}$ : open circuit potential; $\mathrm{E}_{\mathrm{corr}}$ : corrosion potential; $\mathrm{i}_{\text {corr }}$ : corrosion current density; $R_{\mathrm{p}}$ : polarization resistance; $\mathrm{P}$ : porosity; $\mathrm{P}_{\mathrm{e}}$ : protective efficiency.

\begin{tabular}{ccccccc}
\hline Substrate/Coating & $\mathbf{E}_{\mathbf{o c}}(\mathbf{m V})$ & $\mathbf{E}_{\text {corr }}(\mathbf{m V})$ & $\mathbf{i}_{\text {corr }}\left(\boldsymbol{\mu} \mathbf{A} / \mathbf{c m}^{\mathbf{2}}\right)$ & $\boldsymbol{R}_{\mathbf{p}}(\mathbf{k} \cdot \mathbf{\Omega})$ & $\mathbf{P}$ & $\mathbf{P}_{\mathbf{e}}(\mathbf{\%})$ \\
\hline SS & 18 & 34 & 14.689 & 1.703 & - & - \\
SS/TiN & 205 & 101 & 7.734 & 5.981 & 0.247 & 47.3 \\
SS/TiNO & 227 & 164 & 3.385 & 12.150 & 0.107 & 77.0 \\
SS/TiN/TiNO & 243 & 126 & 3.723 & 7.170 & 0.196 & 74.7 \\
SS/TiNO/TiN & 214 & 123 & 6.630 & 6.450 & 0.219 & 54.9 \\
\hline
\end{tabular}

The polarization resistance $R_{\mathrm{p}}$ parameter values are presented in Table 3. In comparison with the uncoated substrate, all the coatings had a higher $R_{\mathrm{p}}$ value (with a factor of 3 to 7 ). The SS/TiNO layer presented the highest polarization resistance value, followed by SS/TiN/TiNO and SS/TiNO/TiN . Moreover, the lower porosity of the TiNO layer (Table 3) could also be a reason for good corrosion behavior of this coating, which might be ascribed to $\mathrm{O}$ addition, which blocked the electrolyte ingress. The combination SS/TiN/TiNO had a higher protective efficiency $\left(\mathrm{P}_{\mathrm{e}}\right)$ than that of SS/TiNO/TiN, indicating that the TiNO monolayer provided better protection against corrosive attack when it was selected as top layer or monolayer because it might form the superficial passive layer more easily. This effect could be related to the double layer, which acts as a more efficient barrier to the electrolyte penetration inside defects present on the surface. The TiN monolayer exhibited the lowest protective efficiency. To summarize the Tafel results, one may observe that TiNO, as a monolayer or top layer of the bilayer, limited the corrosive attack, exhibiting superior corrosion resistance.

If we take into account the monolayer structures, the higher protective efficiency of TiNO compared to TiN can be related to its chemical composition containing oxygen and lower grain size value. According to XRD measurements (Table 2), the oxygen addition in the TiN structure determined the decrease in the values of grain sizes. The loss of long-range order in the oxynitride coating, compared to the nitride coating, might be ascribed to the competition between the growth of titanium nitride and amorphous oxide phases, taking place at the surface, since titanium presents a stronger affinity to oxygen than to nitrogen. The observed amorphization of the oxynitride coatings was consistent with those reported by Bunjongpru et al. [96] on aluminum oxynitrides, as the addition of small amounts of oxygen in the feed gas during deposition hinders the formation of a crystalline structure.

Figure 6 presents the $R_{\mathrm{a}}$ and $R_{\mathrm{q}}$ roughness parameters of the coating at the end of the corrosion tests. Usually, the initial roughness of a coating determines the increase in the electrochemical reactivity and the corrosion process [97-100], as such an increase of the coating roughness was observed at the end of the corrosive attack.

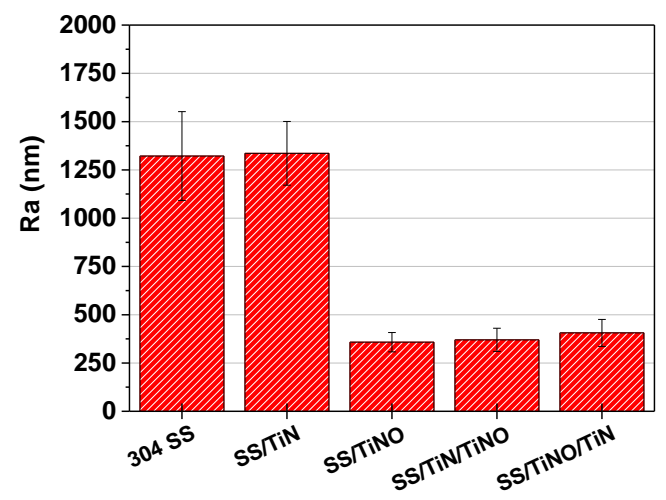

(a)

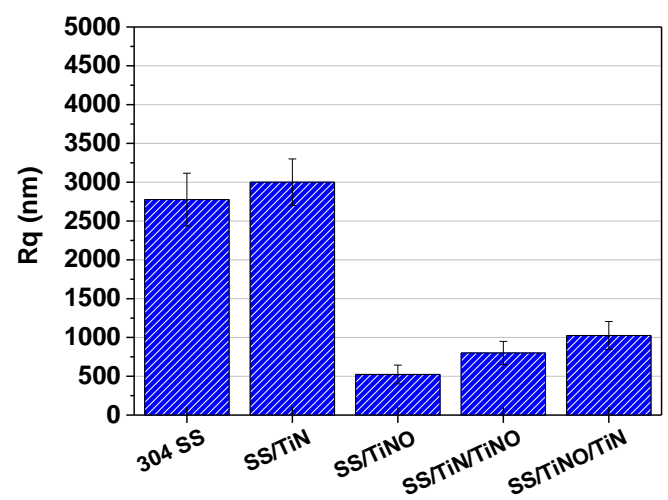

(b)

Figure 6. Roughness parameters after corrosion tests: (a) $R_{\mathrm{a}}$-arithmetic average deviation from the mean line; (b) $R_{\mathrm{q}}$-root mean square average of the profile heights over the evaluation length. 
In the literature, there are many reports that tried to correlate the anticorrosive properties with respect to coating thickness [101-103], doping elements [104-109], grain size values and roughness [110,111], but conclusive regular data are lacking.

By comparing the results presented in Figures 2 and 6, one may observe that the uncoated substrate was significantly affected by the corrosion process, because the $R_{\mathrm{a}}$ value increased after corrosion by a factor of about 50. An important difference in $R_{\mathrm{a}}$ values before and after corrosion attack was found for the TiN monolayer ( 3.2), indicating that its surface was also significantly affected by the corrosion process. Considering all coatings, the poorer corrosion resistance of the TiN coating might be ascribed to the larger grain size and columnar growth, specific for the transition metal nitrides and stoichiometric carbides [111], with deeply separated columns, which accelerates corrosion due to micro electrochemical cells formed, leading to an increase of the corrosion process. The same tendency was found in the case of hafnium nitride (HfN) or Vanadium nitride (VN) coatings [111]. The weak corrosion resistance of TiN can be also ascribed to the presence of numerous microdroplets on its surface, which might represent areas where the corrosion attack can be more active.

The superior corrosion resistance of TiNO as a monolayer, with the smallest grain size, can be explained in connection to the ease of oxynitride passivation [112]. The passivation process starts on the surface with smaller grain sizes, while the corrosion process is more active at the grain boundaries or along defects. The passive layer will prevent the positive Ti ions from migrating toward the surface and participating in the electrochemical reaction, or prevent negative $\mathrm{Cl}^{-}$ions to penetrate inside the surface. Thus, it is accurate to conclude that the coating with smaller grain size exhibited a sizable passive layer (Figure 4), which led to a low corrosion rate. The small increase in roughness for the TiNO monolayer, found after the corrosion tests, indicated that its surface was just slightly polished by the corrosion process, probably the highest peaks were flattened. Comparing all coatings, the low roughness of the TiNO monolayer, providing a low surface for the contact with the electrolyte, hindered the abundant formation of microelectrochemical cells by minimizing penetration of chlorine ions inside the valleys found on the surface, resulting in superior corrosion resistance of TiNO monolayer.

For the bilayers, the differences in roughness before and after corrosion were not substantial, just a slight increase in $R_{a}$ was observed after corrosion tests, signifying that these surfaces were less affected by the corrosion process. Related to both corrosion resistance and roughness, the obtained results placed them, as expected, between TiNO and TiN monolayers. The top layer in the bilayer influenced both the roughness and the corrosion resistance, thus the SS/TiNO/TiN coating, with the TiN layer facing the corrosive solution, was more prone to corrosion and presented an increased roughness, compared to the SS/TiN/TiNO bilayer.

Figure 7 presents the surface morphology of all coatings at the end of the corrosion tests. On the surface of the TiN monolayer, many corroded particles were seen, as well as some pits, while on the TiNO surface, only some corroded particles were found, indicating that the oxynitride coating exhibited a better corrosion resistance. Regarding the bilayers, pits were observed on both surfaces, and corroded particles were more noticeable on the SS/TiNO/TiN bilayer. As observed, the larger size defects were evident on the SS/TiN coating, while on the SS/TiNO, the number and size of defects were lower. It is known that the columnar growth of TiN and its isostructural TiNO coatings provides small pores, such that, after immersion in a corrosive solution, the galvanic corrosion develops for the unmatched corrosion potentials of the substrate and the coatings, and the corrosion evolution depends also on the coating thickness. The action of the $\mathrm{H}_{2} \mathrm{O}_{2}$-augmented saline solution was more severe on the coatings of the TiN material exposed to the saline solution, with smaller grain size, increased surface roughness, and sharp edges (Figure $3 b$ ), increasing the corrosion attack on the sharp features. The SEM images after the corrosion tests are in good agreement with the corrosion results, the roughness parameters values, the grain size, and the thickness of individual layers.

Based upon the corrosion resistance and the coatings adhesion results, we may conclude that the most valuable candidate as a biocompatible coating for austenitic 304 stainless steel alloy is represented 
by the SS/TiN/TiNO bilayer due to its highest adhesion to the metal substrate and the superior corrosion resistance, with corrosion parameters closely similar to the TiNO monolayer.

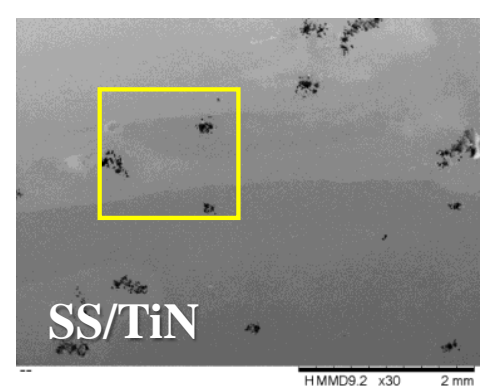

(a)

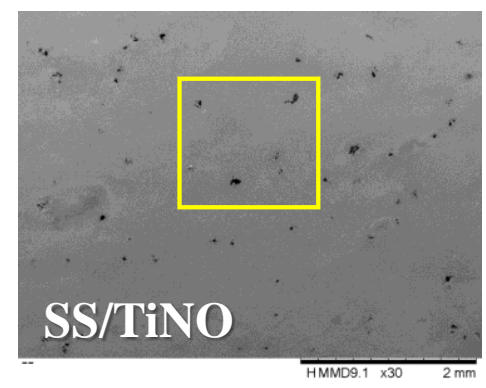

(c)

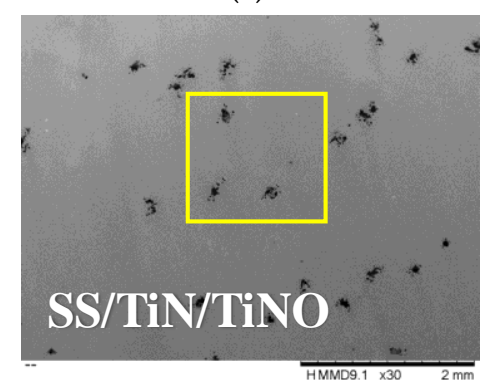

(e)

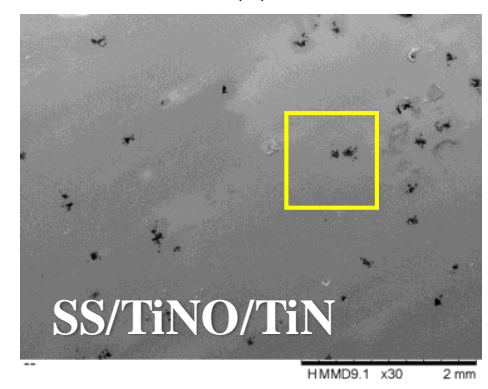

(g)

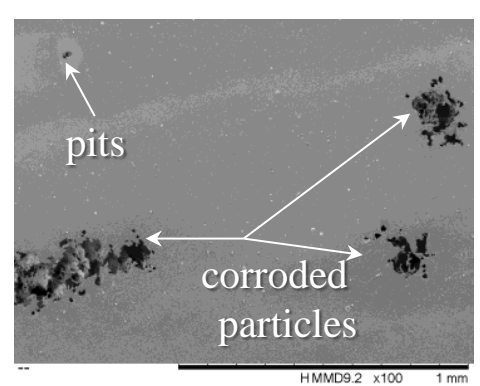

(b)

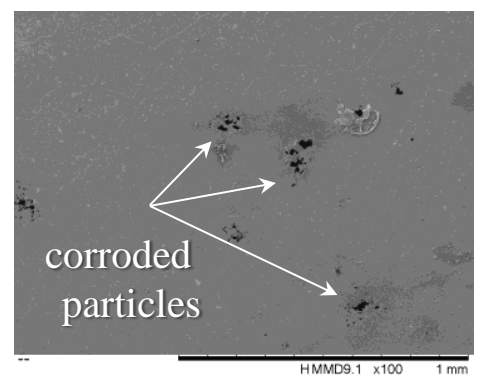

(d)

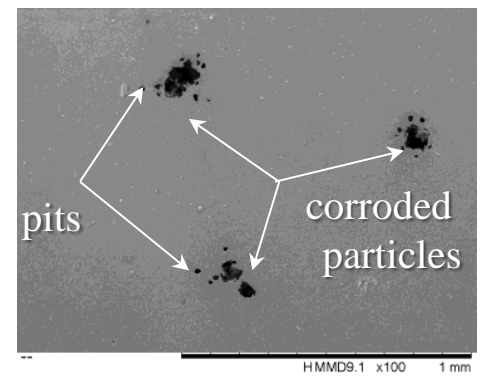

(f)

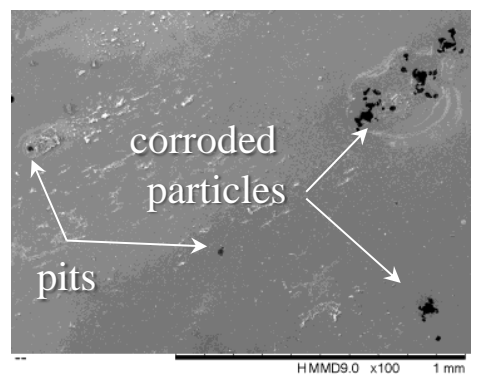

(h)

Figure 7. Surface morphology of all coatings at the end of the corrosion tests obtained by SEM: (a) SS/TiN coating ( $\times 30$ magnification); (b) SS/TiN coating ( $\times 100$ magnification) corresponding to the yellow square in Figure 7a; (c) SS/TiNO coating ( $\times 30$ magnification); (d) SS/TiNO coating $(\times 100$ magnification), corresponding to the yellow square in Figure 7c; (e) SS/TiN/TiNO coating ( $\times 30$ magnification); (f) SS/TiN/TiNO coating ( $\times 100$ magnification) corresponding to the yellow square in Figure 7e; (g) SS/TiNO/TiN coating ( $\times 30$ magnification); (h) SS/TiNO/TiN coating ( $\times 100$ magnification), corresponding to the yellow square in Figure $7 \mathrm{~g}$. 


\section{Conclusions}

Ti-based coatings deposited on 304 SS substrate were successfully prepared by the cathodic arc method in both mono and bilayered structures. The XRD diffraction patterns showed only TiN phases with rock-salt structure and (111) and (222) preferred orientations. The TiNO monolayer and the bilayer with TiNO on top were smooth and homogenous, having a low number of microdroplets.

The oxygen addition in TiN structure decreased the grain size, with a higher density of nucleation sites for the passive film, resulting in an enhanced formation of a passive layer and thus a superior corrosion resistance. All coated substrates showed better in vitro corrosion resistance than the bare substrate, with lower current density and higher corrosion potential values. The SS/TiN/TiNO bilayer presented a higher protective efficiency than the SS/TiNO/TiN bilayer, indicating that TiNO, as a monolayer or top layer in the bilayer, determines the best protection against corrosive attack.

The coatings facing the environment with a TiNO layer represent valuable candidates as a biocompatible coating for austenitic 304 stainless steel due to their strong corrosion resistance in an aggressive saline environment.

Author Contributions: Conceptualization, V.B.; coatings deposition, I.P. and M.B.; characterization, M.D., E.S.M.M., I.P., and A.C.P., data analysis, V.B., L.F.P., and M.B.; resources, V.B., original draft, M.D. and E.S.M.M., writing-review and editing, V.B., L.F.P., and M.B. All authors have read and agreed to the published version of the manuscript.

Funding: This work was supported by a grant of the Romanian National Authority for Scientific Research and Innovation CCCDI-UEFISCDI, project COFUND-ERANET EURONANOMED 3-NANO-VERTEBRA, within PNCDI III (no. 91/2019), and by the Core Program 18N/2019. The authors are grateful for the financial support of a grant of the Bilateral Cooperation South Africa-Romania Projects (no. PN-II-CT-RO-ZA-2014-1 and NRF project reference no. UID: 104018, as acknowledged by NRF/RISA Reference RJCT14042566606) signed between the Romanian National Authority for Scientific Research and Innovation, CNCS-UEFISCDI, and the South Africa National Research Foundation. Financial support was also provided by PROINSTITUTIO Project-contract No. 19PFE/17.10.2018. The EDS, SEM, and adhesion results were obtained using the systems purchased by the infrastructure project INOVA-OPTIMA SMIS code 49164, contract No. 658/2014.

Conflicts of Interest: The authors declare no conflict of interest. The founding sponsors had no role in the design of the research; in the collection, analyses, or interpretation of data; in the writing of the manuscript, and in the decision to publish the results.

\section{References}

1. Sippel, T.; He, X.; Ahn, T. Corrosion of Borated Stainless Steel in Water and Humid Air; USA Nuclear Regulatory Commission: Washington, DC, USA, 2011.

2. Burkert, A.; Müller, T.; Lehmann, J.; Mietz, J. Long-term corrosion behaviour of stainless steels in marine atmosphere. Mater. Corros. 2018, 69, 20-28. [CrossRef]

3. Liu, W.; Lu, S.L.; Zhang, Y.; Fang, Z.C.; Wang, X.M.; Lu, M.X. Corrosion performance of 3\% Cr steel in CO2-H2S environment compared with carbon steel. Mater. Corros. 2015, 66, 1232-1244. [CrossRef]

4. Zhang, L.; Wang, J. Effect of dissolved oxygen content on stress corrosion cracking of a cold worked 316L stainless steel in simulated pressurized water reactor primary water environment. J. Nucl. Mater. 2014, 446, 15-26. [CrossRef]

5. Abbasi Aghuy, A.; Zakeri, M.; Moayed, M.H.; Mazinani, M. Effect of grain size on pitting corrosion of 304L austenitic stainless steel. Corros. Sci. 2015, 94, 368-376. [CrossRef]

6. Mackey, E.D.; Seacord, T.F. Guidelines for using stainless steel in the water and desalination industries. J. Am. Water Works Assoc. 2017, 109, 158-169. [CrossRef]

7. Manivasagam, G.; Dhinasekaran, D.; Rajamanickam, A. Biomedical implants: corrosion and its prevention-A review. Recent Pat. Corros. Sci. 2010, 2, 40-54. [CrossRef]

8. Blackwood, D.J.; Pereira, B.P. No corrosion of 304 stainless steel implant after 40 years of service. J. Mater. Sci. Mater. Med. 2004, 15, 755-758. [CrossRef]

9. Liang, W. Surface modification of AISI 304 austenitic stainless steel by plasma nitriding. Appl. Surf. Sci. 2003, 211, 308-314. [CrossRef]

10. Wang, J.; Shi, H. The study of surface modification 304 stainless steel in simulated PEMFC environments. Adv. Mater. Res. 2013, 608-609, 865-869. [CrossRef] 
11. Wang, G.Q.; Lei, M.K.; Guo, D.M. Interactions between Surface Integrity Parameters on AISI 304 Austenitic Stainless Steel Components by Ultrasonic Impact Treatment. Procedia CIRP 2016, 45, 323-326. [CrossRef]

12. Bao, Z.; Wang, C.; Zhang, Y.; Zhao, Q.-Z. Modification of wettability of stainless steel by picosecond laser surface microstructuring. Photonics Res. 2015, 3, 180. [CrossRef]

13. Beaumier, E.P.; Pearce, A.J.; See, X.Y.; Tonks, I.A. Modern applications of low-valent early transition metals in synthesis and catalysis. Nat. Rev. Chem. 2019, 3, 15-34. [CrossRef] [PubMed]

14. Hafeez, N.; Liu, J.; Wang, L.; Wei, D.; Tang, Y.; Lu, W.; Zhang, L.C. Superelastic response of low-modulus porous beta-type Ti-35Nb-2Ta-3Zr alloy fabricated by laser powder bed fusion. Addit. Manuf. 2020, 34, 101264. [CrossRef]

15. Liu, S.; Liu, J.; Wang, L.; Ma, R.L.W.; Zhong, Y.; Lu, W.; Zhang, L.C. Superelastic behavior of in-situ eutectic-reaction manufactured high strength 3D porous NiTi-Nb scaffold. Scr. Mater. 2020, 181, 121-126. [CrossRef]

16. Wang, L.; Xie, L.; Zhang, L.C.; Chen, L.; Ding, Z.; Lv, Y.; Zhang, W.; Lu, W.; Zhang, D. Microstructure evolution and superelasticity of layer-like $\mathrm{NiTiNb}$ porous metal prepared by eutectic reaction. Acta Mater. 2018, 143, 214-226. [CrossRef]

17. Zhang, L.C.; Chen, L.Y.; Wang, L. Surface Modification of Titanium and Titanium Alloys: Technologies, Developments, and Future Interests. Adv. Eng. Mater. 2020, 22. [CrossRef]

18. Licausi, M.P.; Igual Muñoz, A.; Amigó Borrás, V. Influence of the fabrication process and fluoride content on the tribocorrosion behaviour of Ti6Al4V biomedical alloy in artificial saliva. J. Mech. Behav. Biomed. Mater. 2013, 20, 137-148. [CrossRef]

19. Fadlallah, S.A.; El-Bagoury, N.; Gad El-Rab, S.M.F.; Ahmed, R.A.; El-Ousamii, G. An overview of NiTi shape memory alloy: Corrosion resistance and antibacterial inhibition for dental application. J. Alloy. Compd. 2014, 583, 455-464. [CrossRef]

20. Lazar, A.-M.; Yespica, W.P.; Marcelin, S.; Pébère, N.; Samélor, D.; Tendero, C.; Vahlas, C. Corrosion protection of 304L stainless steel by chemical vapor deposited alumina coatings. Corros. Sci. 2014, 81, 125-131. [CrossRef]

21. Volovitch, P.; Vu, T.N.; Allély, C.; Abdel Aal, A.; Ogle, K. Understanding corrosion via corrosion product characterization: II. Role of alloying elements in improving the corrosion resistance of $\mathrm{Zn}-\mathrm{Al}-\mathrm{Mg}$ coatings on steel. Corros. Sci. 2011, 53, 2437-2445. [CrossRef]

22. Krishna, N.G.; Thinaharan, C.; George, R.P.; Parvathavarthini, N.; Kamachi Mudali, U. Surface modification of type 304 stainless steel with duplex coatings for corrosion resistance in sea water environments. Surf. Eng. 2015, 31, 39-47. [CrossRef]

23. Jiao, Z.; Peterkin, S.; Felix, L.; Liang, R.; Oliveira, J.P.; Schell, N.; Scotchmer, N.; Toyserkani, E.; Zhou, Y. Surface Modification of 304 Stainless Steel by Electro-Spark Deposition. J. Mater. Eng. Perform. 2018, 27, 4799-4809. [CrossRef]

24. Modiri, F.; Savaloni, H. A study of the corrosion of stainless steel 304L coated with a $190 \mathrm{~nm}$-thick manganese layer and annealed with nitrogen flux in a 0.4-mole solution of $\mathrm{H} 2 \mathrm{SO} 4$ at different temperatures. J. Theor. Appl. Phys. 2020, 14, 21-35. [CrossRef]

25. Zhang, S.; Zhu, W. TiN coating of tool steels: A review. J. Mater. Process. Tech. 1993, 39, 165-177. [CrossRef]

26. Jindal, P.C.; Santhanam, A.T.; Schleinkofer, U.; Shuster, A.F. Performance of PVD TiN, TiCN, and TiAlN coated cemented carbide tools in turning. Int. J. Refract. Met. Hard Mater. 1999, 17, 163-170. [CrossRef]

27. Deng, J.; Liu, J.; Ding, Z.; Niu, M. Unlubricated friction and wear behaviors of ZrN coatings against hardened steel. Mater. Des. 2008, 29, 1828-1834. [CrossRef]

28. Atar, E.; Alpaslan, Ö.; Çelik, Ö.; Çimenoĝlu, H. Tribological properties of CrN coated H13 grade tool steel. J. Iron Steel Res. Int. 2014, 21, 240-245. [CrossRef]

29. Birol, Y. Sliding wear of $\mathrm{CrN}, \mathrm{AlCrN}$ and AlTiN coated AISI H13 hot work tool steels in aluminium extrusion. Tribol. Int. 2013, 57, 101-106. [CrossRef]

30. Sresomroeng, B.; Premanond, V.; Kaewtatip, P.; Khantachawana, A.; Kurosawa, A.; Koga, N. Performance of CrN radical nitrided tools on deep drawing of advanced high strength steel. Surf. Coat. Technol. 2011, 205, 4198-4204. [CrossRef]

31. Li, K.-H.; Alfaraj, N.; Kang, C.H.; Braic, L.; Zoita, N.C.; Kiss, A.E.; Ng, T.K.; Ooi, B. Deep-ultraviolet beta-Ga2O3 photodetectors grown on $\mathrm{MgO}$ substrates with a TiN template. In Proceedings of the 2019 IEEE Photonics Conference (IPC), San Antonio, TX, USA, 29 September-3 October 2019; IEEE: Piscataway, NJ, USA, 2019. 
32. Balaceanu, M.; Braic, V.; Braic, M.; Kiss, A.; Zoita, C.N.; Vladescu, A.; Drob, P.; Vasilescu, C.; Dudu, D.; Muresanu, O. Structural, mechanical and corrosion properties of TiOxNy/ZrOxNy multilayer coatings. Surf. Coat. Technol. 2008, 202. [CrossRef]

33. Braic, M.; Balaceanu, M.; Vladescu, A.; Kiss, A.; Braic, V.; Epurescu, G.; Dinescu, G.; Moldovan, A.; Birjega, R.; Dinescu, M. Preparation and characterization of titanium oxy-nitride thin films. Appl. Surf. Sci. 2007, 253, 8210-8214. [CrossRef]

34. Subramanian, B.; Muraleedharan, C.V.; Ananthakumar, R.; Jayachandran, M. A comparative study of titanium nitride (TiN), titanium oxy nitride (TiON) and titanium aluminum nitride (TiAlN), as surface coatings for bio implants. Surf. Coat. Technol. 2011, 205, 5014-5020. [CrossRef]

35. Cubillos, G.I.; Bethencourt, M.; Olaya, J.J.; Alfonso, J.E.; Marco, J.F. The influence of deposition temperature on microstructure and corrosion resistance of $\mathrm{ZrOxNy} / \mathrm{ZrO} 2$ coatings deposited using RF sputtering. Appl. Surf. Sci. 2014, 309, 181-187. [CrossRef]

36. Alves, E.; Ramos, A.R.; Barradas, N.P.; Vaz, F.; Cerqueira, P.; Rebouta, L.; Kreissig, U. Ion beam studies of TiNxOy thin films deposited by reactive magnetron sputtering. Surf. Coat. Technol. 2004, 180-181, 372-376. [CrossRef]

37. Jung, M.J.; Nam, K.H.; Chung, Y.M.; Boo, J.H.; Han, J.G. The physiochemical properties of TiOxNyfilms with controlled oxygen partial pressure. Surf. Coat. Technol. 2003, 171, 71-74. [CrossRef]

38. Vaz, F.; Cerqueira, P.; Rebouta, L.; Nascimento, S.M.C.; Alves, E.; Goudeau, P.; Rivière, J.P. Preparation of magnetron sputtered TiNxOy thin films. Surf. Coat. Technol. 2003, 174-175, 197-203. [CrossRef]

39. Cotrut, C.M.; Braic, L.; Vranceanu, D.M.; Kiss, A.; Dinu, M.; Balaceanu, M.; Braic, V.; Vladescu, A. Influence of the annealing treatment on the structure, morphology, and corrosion resistance of sputtered $\mathrm{Zr}-\mathrm{Ti}-\mathrm{Si}-\mathrm{O}$ coatings used for biomedical applications. Mater. Corros. 2017, 68, 552-559. [CrossRef]

40. Sollazzo, V.; Pezzetti, F.; Scarano, A.; Piattelli, A.; Bignozzi, C.A.; Massari, L.; Brunelli, G.; Carinci, F. Zirconium oxide coating improves implant osseointegration in vivo. Dent. Mater. 2008, 24, 357-361. [CrossRef]

41. Giavaresi, G.; Giardino, R.; Ambrosio, L.; Battiston, G.; Gerbasi, R.; Fini, M.; Rimondini, L.; Torricelli, P. In vitro biocompatibility of titanium oxide for prosthetic devices nanostructured by low pressure metal-organic chemical vapor deposition. Int. J. Artif. Organs 2003, 26, 774-780. [CrossRef]

42. Dinu, M.; Braic, L.; Padmanabhan, S.C.; Morris, M.A.; Titorencu, I.; Pruna, V.; Parau, A.; Romanchikova, N.; Petrik, L.F.; Vladescu, A. Characterization of electron beam deposited Nb2O5 coatings for biomedical applications. J. Mech. Behav. Biomed. Mater. 2020, 103, 103582. [CrossRef]

43. Scopel, W.L.; Fantini, M.C.A.; Alayo, M.I.; Pereyra, I. Local structure and bonds of amorphous silicon oxynitride thin films. Thin Solid Film. 2002, 413, 59-64. [CrossRef]

44. Kazemeini, M.H.; Berezin, A.A.; Fukuhara, N. Formation of thin TiN x O y films by using a hollow cathode reactive DC sputtering system. Thin Solid Film. 2000, 372, 70-77. [CrossRef]

45. Nasir, M.E.; Peruch, S.; Vasilantonakis, N.; Wardley, W.P.; Dickson, W.; Wurtz, G.A.; Zayats, A.V. Tuning the effective plasma frequency of nanorod metamaterials from visible to telecom wavelengths. Appl. Phys. Lett. 2015, 107. [CrossRef]

46. Rtimi, S.; Baghriche, O.; Sanjines, R.; Pulgarin, C.; Bensimon, M.; Kiwi, J. TiON and TiON-Ag sputtered surfaces leading to bacterial inactivation under indoor actinic light. J. Photochem. Photobiol. A Chem. 2013, 256, 52-63. [CrossRef]

47. Braic, L.; Vasilantonakis, N.; Mihai, A.; Garcia, I.J.V.; Fearn, S.; Zou, B.; Alford, N.M.; Doiron, B.; Oulton, R.F.; Maier, S.A.; et al. Titanium Oxynitride Thin Films with Tunable Double Epsilon-Near-Zero Behavior for Nanophotonic Applications. ACS Appl. Mater. Interfaces 2017, 9, 29857-29862. [CrossRef]

48. Duta, O.C.; Ficai, D.; Ficai, A.; Andronescu, E.; Beshchasna, N.; Saqib, M.; Opitz, J.; Kraśkiewicz, H.; Wasyluk, Ł.; Kuzmin, O.; et al. Titanium oxynitride coatings deposited by magnetron sputtering for improvement of cardiovascular stent design. In Proceedings of the World Congress on New Technologies, Madrid, Spain, 19-21 August 2018; pp. 18-20.

49. Braic, M.; Braic, V.; Balaceanu, M.; Kiss, A.; Cotrut, C.; Drobe, P.; Vladescu, A.; Vasilescu, C. On some characteristics of Ti oxynitrides obtained by pulsed magnetron sputtering. Plasma Process. Polym. 2007, 4. [CrossRef]

50. Ahmed, M.; Xinxin, G. A review of metal oxynitrides for photocatalysis. Inorg. Chem. Front. 2016, 3, 578-590. [CrossRef] 
51. Asahi, R.; Morikawa, T.; Ohwaki, T.; Aoki, K.; Taga, Y. Visible-light photocatalysis in nitrogen-doped titanium oxides. Science 2001, 293, 269-271. [CrossRef]

52. El-Fattah, H.A.A.; El-Mahallawi, I.S.; Shazly, M.H.; Khalifa, W.A. Optical properties and microstructure of TiNxOy and TiN thin films before and after annealing at different conditions. Coatings 2019, 9, 22. [CrossRef]

53. Dunn, D.S. An electrochemical approach to predicting longterm localized corrosion of corrosion-resistant high-level waste container materials. Corrosion 2000, 56, 90-104. [CrossRef]

54. Tsyganov, I.A.; Maitz, M.F.; Richter, E.; Reuther, H.; Mashina, A.I.; Rustichelli, F. Hemocompatibility of titanium-based coatings prepared by metal plasma immersion ion implantation and deposition. Nucl. Instrum. Methods Phys. Res. Sect. B Beam Interact. Mater. At. 2007, 257, 122-127. [CrossRef]

55. Venkataraj, S.; Severin, D.; Mohamed, S.H.; Ngaruiya, J.; Kappertz, O.; Wuttig, M. Towards understanding the superior properties of transition metal oxynitrides prepared by reactive DC magnetron sputtering. Thin Solid Film. 2006, 502, 228-234. [CrossRef]

56. Colović, B.; Kisić, D.; Jokanović, B.; Rakočević, Z.; Nasov, I.; Petkoska, A.T.; Jokanović, V. Wetting properties of titanium oxides, oxynitrides and nitrides obtained by DC and pulsed magnetron sputtering and cathodic arc evaporation. Mater. Sci. Pol. 2019, 37, 173-181. [CrossRef]

57. Braic, V.; Zoita, C.N.N.; Balaceanu, M.; Kiss, A.; Vladescu, A.; Popescu, A.; Braic, M. TiAlN/TiAlZrN multilayered hard coatings for enhanced performance of HSS drilling tools. Surf. Coat. Technol. 2010, 204, 1925-1928. [CrossRef]

58. Sadeghimeresht, E. Electrochemical Behavior of Bilayer Thermal-Spray Coatings in Low-Temperature Corrosion Protection. Coatings 2017, 7, 162. [CrossRef]

59. Dinu, M.; Mouele, E.S.M.; Parau, A.C.; Vladescu, A.; Petrik, L.F.; Braic, M. Enhancement of the corrosion resistance of 304 stainless steel by $\mathrm{Cr}-\mathrm{N}$ and $\mathrm{Cr}(\mathrm{N}, \mathrm{O})$ coatings. Coatings 2018, 8, 132. [CrossRef]

60. Alegría-Ortega, J.; Ocampo-Carmona, L.M.; Rodríguez, F.; Forlerer, E. Cr/CrN bilayer coating behavior under erosion-corrosion degradation by jet impingement testing Comportamiento de un recubrimiento bicapa de Cr/CrN bajo degradación por erosión-corrosión por ensayo de impacto con chorro. Dyna 2016, 83, 146-153. [CrossRef]

61. Braic, M.; Balaceanu, M.; Vladescu, A.; Kiss, A.; Braic, V.; Purice, A.; Dinescu, G.; Scarisoreanu, N.; Stokker-Cheregi, F.; Moldovan, A.; et al. TiN/ZrN heterostructures deposition and characterisation. Surf. Coat. Technol. 2006, 200. [CrossRef]

62. Boveris, A.; Oshino, N.; Chance, B. The cellular production of hydrogen peroxide. Biochem. J. 1972, 128, 617-630. [CrossRef]

63. Halliwell, B.; Clement, M.V.; Long, L.H. Hydrogen peroxide in the human body. FEBS Lett. 2000, 486, 10-13. [CrossRef]

64. Satoh, T.; Uchida, S.; Sugama, J.I.; Yamashiro, N.; Hirose, T.; Morishima, Y.; Satoh, Y.; Iinuma, K. Effects of hydrogen peroxide on corrosion of stainless steel, (I) improved control of hydrogen peroxide remaining in a high temperature high pressure hydrogen peroxide loop. J. Nucl. Sci. Technol. 2004, 41, 610-618. [CrossRef]

65. Al Kharafi, F.M.; Ghayad, I.M.; Abdullah, R.M. Effect of hydrogen peroxide on the dezincification of brass in acidified sodium sulfate solution under free corrosion conditions. J. Mater. Environ. Sci. 2010, 1, 58-69.

66. Zhang, Y.; Addison, O.; Yu, F.; Troconis, B.C.R.; Scully, J.R.; Davenport, A.J. Time-dependent enhanced corrosion of Ti6Al4V in the presence of $\mathrm{H}_{2} \mathrm{O}_{2}$ and albumin. Sci. Rep. 2018, 8, 1-11. [CrossRef]

67. Dinu, M.; Hauffman, T.; Cordioli, C.; Vladescu, A.; Braic, M.; Hubin, A.; Cotrut, C.M.C.M. Protective performance of $\mathrm{Zr}$ and $\mathrm{Cr}$ based silico-oxynitrides used for dental applications by means of potentiodynamic polarization and odd random phase multisine electrochemical impedance spectroscopy. Corros. Sci. 2017, 115, 118-128. [CrossRef]

68. Braic, L.; Zoita, N.C. Influence of the deposition time and temperature on the texture of InN thin films grown by RF-magnetron sputtering. Optoelectron. Adv. Mater. Rapid Commun. 2010, 4, 2013-2017.

69. Deutsches Institut fur Normung E.V. Norm Advanced Technical Ceramics-Methods of Test for Ceramic Coatings-Part 3: Determination of Adhesion and Other Mechanical Failure Modes by a Scratch Test; DIN: Berlin, Germany, 2003.

70. Pace, M.T.; Thomson, R.C.; Wells, J.; Peterson, W.; Gould, J.E.; Barnes, D.J.; American Society for Testing and Materials; Paul, S. ASTM C1624-05: Standard Test Method for Adhesion Strength and Mechanical Failure Modes of Ceramic by Quantitative Single Point Scratch Testing. Coatings 2015. [CrossRef] 
71. Stern, M.; Geary, L. Electrochemical polarization I. A theoritical analysis of the shape of polarization curves. J. Electrochem. Soc. 1957, 104, 56-63. [CrossRef]

72. Pruncu, C.I.C.I.; Braic, M.; Dearn, K.D.K.D.; Farcau, C.; Watson, R.; Constantin, L.R.L.R.; Balaceanu, M.; Braic, V.; Vladescu, A. Corrosion and tribological performance of quasi-stoichiometric titanium containing carbo-nitride coatings. Arab. J. Chem. 2017, 10, 1015-1028. [CrossRef]

73. Vladescu, A.; Vranceanu, D.M.D.M.; Kulesza, S.; Ivanov, A.N.A.N.; Bramowicz, M.; Fedonnikov, A.S.A.S.; Braic, M.; Norkin, I.A.I.A.; Koptyug, A.; Kurtukova, M.O.M.O.; et al. Influence of the electrolyte's pH on the properties of electrochemically deposited hydroxyapatite coating on additively manufactured Ti64 alloy. Sci. Rep. 2017, 7, 1-20. [CrossRef]

74. Dudin, S.; Cotrut, C.M.; Dinu, M.; Zykova, A.; Parau, A.C.; Yakovin, S.; Vladescu, A. Comparative study of the hydroxyapatite coatings prepared with/without substrate bias. Ceram. Int. 2017, 43, 14968-14975. [CrossRef]

75. International Centre for Diffraction Data. Powder Diffraction File: 04-017-6803, JCPDS; ICCD: Delaware County, PA, USA, 2010.

76. Scherrer, P. Bestimmung der Grosse und der Inneren Struktur von Kolloidteilchen Mittels Rontgenstrahlen. Nachrichten von der Gesellschaft der Wissenschaften, Gottingen, Mathematisch-Physikalische Klasse 1918, 1918, 98-100.

77. Huang, C.N.; Bow, J.S.; Zheng, Y.; Chen, S.Y.; Ho, N.J.; Shen, P. Nonstoichiometric titanium oxides via pulsed laser ablation in water. Nanoscale Res. Lett. 2010, 5, 972-985. [CrossRef]

78. Jokanović, V.; Čolović, B.; Bundaleski, N.; Jokanović, M.; Petkoska, A.T.; Ferrara, M.; Nasov, I.; Rakočević, Z. TixOy thin films with extremely low extinction coefficients obtained by pulsed magnetron sputtering. J. Optoelectron. Adv. Mater. 2018, 20,169-174.

79. Wennerberg, A.; Albrektsson, T. Suggested guidelines for the topographic evaluation of implant surfaces. Int. J. Oral. Maxillofac. Implant. 2000, 15, 331-344.

80. Mendonça, G.; Mendonça, D.B.S.; Aragão, F.J.L.; Cooper, L.F. Advancing dental implant surface technology-From micron- to nanotopography. Biomaterials 2008, 29, 3822-3835. [CrossRef] [PubMed]

81. Webster, T.J.; Ejiofor, J.U. Increased osteoblast adhesion on nanophase metals: Ti, Ti6Al4V, and CoCrMo. Biomaterials 2004, 25, 4731-4739. [CrossRef]

82. Hao, L.; Lawrence, J.; Phua, Y.F.; Chian, K.S.; Lim, G.C.; Zheng, H.Y. Enhanced human osteoblast cell adhesion and proliferation on 316 LS stainless steel by means of CO2 laser surface treatment. J. Biomed. Mater. Res. Part B Appl. Biomater. 2005, 73, 148-156. [CrossRef]

83. Abadias, G.; Michel, A.; Tromas, C.; Jaouen, C.; Dub, S.N. Stress, interfacial effects and mechanical properties of nanoscale multilayered coatings. Surf. Coat. Technol. 2007, 202, 844-853. [CrossRef]

84. Samal, S.; Tyc, O.; Heller, L.; Šittner, P.; Malik, M.; Poddar, P.; Catauro, M.; Blanco, I. Study of interfacial adhesion between nickel-titanium shape memory alloy and a polymer matrix by laser surface pattern. Appl. Sci. 2020, 10, 2172. [CrossRef]

85. Helmersson, U.; Todorova, S.; Barnett, S.A.; Sundgren, J.E.; Markert, L.C.; Greene, J.E. Growth of single-crystal TiN/VN strained-layer superlattices with extremely high mechanical hardness. J. Appl. Phys. 1987, 62, 481-484. [CrossRef]

86. Mirkarimi, P.B.; Hultman, L.; Barnett, S.A. Enhanced hardness in lattice-matched single-crystal TiN/V 0.6Nb0.4N superlattices. Appl. Phys. Lett. 1990, 57, 2654-2656. [CrossRef]

87. Wiberg, N.; Holleman, A.F.; Wiberg, E. Inorganic Chemistry; Wiberg, N., Ed.; Academic Press: San Diego, CA, USA; New York, NY, USA; De Gruyter: Berlin, Germany; San Diego, CA, USA; New York, NY, USA, 2001.

88. Velasco, L.; Olaya, J.J.; Rodil, S.E. Effect of Si addition on the structure and corrosion behavior of $\mathrm{NbN}$ thin films deposited by unbalanced magnetron sputtering. Appl. Phys. A Mater. Sci. Process. 2016, 122, 1-10. [CrossRef]

89. Zhang, X.G. Corrosion potential and corrosion current. In Corrosion and Electrochemistry of Zinc; Zhang, X.G., Ed.; Springer: Boston, MA, USA, 1996; pp. 125-156. ISBN 978-1-4757-9877-7.

90. Ding, J.C.; Wang, Q.M.; Liu, Z.R.; Jeong, S.; Zhang, T.F.; Kim, K.H. Influence of bias voltage on the microstructure, mechanical and corrosion properties of AlSiN films deposited by HiPIMS technique. J. Alloy. Compd. 2019, 772, 112-121. [CrossRef]

91. Kertzman, Z.; Marchal, J.; Suarez, M.; Staia, M.H.; Filip, P.; Kohli, P.; Aouadi, S.M. Mechanical, tribological, and biocompatibility properties of $\mathrm{ZrN}-\mathrm{Ag}$ nanocomposite films. J. Biomed. Mater. Res. Part A 2008, 84, 1061-1067. [CrossRef] 
92. Pressouyre, G.M.; Bernstein, I.M. An example of the effect of hydrogen trapping on hydrogen embrittlement. Metall. Trans. A 1981, 12, 835-844. [CrossRef]

93. Darken, L.S.; Smith, R.P. Behaviour of hydrogen in steel during and after immersion in acid. Corrosion 1948, 5, 1-16. [CrossRef]

94. Kirkland, N.T.; Schiller, T.; Medhekar, N.; Birbilis, N. Exploring graphene as a corrosion protection barrier. Corros. Sci. 2012, 56, 1-4. [CrossRef]

95. Ahmad, Z. Corrosion Kinetics. In Principles of Corrosion Engineering and Corrosion Control; Elsevier: Amsterdam, The Netherlands, 2006; pp. 57-119.

96. Bunjongpru, W.; Porntheeraphat, S.; Somwang, N.; Khomdet, P.; Hruanun, C.; Poyai, A.; Nukeaw, J. Oxygen control on nanocrystal-AlON Films by reactive gas-timing technique RF magnetron sputtering and annealing effect. Adv. Mater. Res. 2008, 55-57, 573-576. [CrossRef]

97. Cachet, H.; Debiemme-Chouvy, C.; Deslouis, C.; Lagrini, A.; Vivier, V. Correlation between electrochemical reactivity and surface chemistry of amorphous carbon nitride films. Surf. Interface Anal. 2006, 38, 719-722. [CrossRef]

98. Park, I.T.; Kim, W.; Kim, E.J.; Bae, S.E.; Kim, J.Y.; Shin, H.C. Electrochemical reactivity of chemically roughened tungsten electrodes. Asian J. Chem. 2013, 25, 7037-7040. [CrossRef]

99. Gira, M.J.; Tkacz, K.P.; Hampton, J.R. Physical and electrochemical area determination of electrodeposited $\mathrm{Ni}, \mathrm{Co}$, and NiCo thin films. Nano Converg. 2016, 3, 6. [CrossRef] [PubMed]

100. Sivakumar, B.; Pathak, L.C.; Singh, R. Role of surface roughness on corrosion and fretting corrosion behaviour of commercially pure titanium in Ringer's solution for bio-implant application. Appl. Surf. Sci. 2017, 401, 385-398. [CrossRef]

101. Rocha, L.A.; Ariza, E.; Ferreira, J.; Vaz, F.; Ribeiro, E.; Rebouta, L.; Alves, E.; Ramos, A.R.; Goudeau, P.; Rivière, J.P. Structural and corrosion behaviour of stoichiometric and substoichiometric TiN thin films. Surf. Coat. Technol. 2004, 180-181, 158-163. [CrossRef]

102. Subramanian, B.; Ananthakumar, R.; Jayachandran, M. Structural and tribological properties of DC reactive magnetron sputtered titanium/titanium nitride (Ti/TiN) multilayered coatings. Surf. Coat. Technol. 2011, 205, 3485-3492. [CrossRef]

103. Patel, N.S.; Menghani, J.; Pai, K.B.; Totlani, M.K. Corrosion behavior of Ti2N thin films in various corrosive environments. J. Mater. Environ. Sci. 2010, 1, 34-43.

104. Li, S.; Fu, J. Improvement in corrosion protection properties of $\mathrm{TiO} 2$ coatings by chromium doping. Corros. Sci. 2013, 68, 101-110. [CrossRef]

105. Hassannejad, H.; Shahrabi, T.; Malekmohammadi, F.; Shanaghi, A.; Aliofkhazraei, M.; Oskuie, A. Effect of cerium doping on corrosion resistance of amorphous silica-titanium sol-gel coating. Curr. Appl. Phys. 2010, 10, 1022-1028. [CrossRef]

106. Sedira, S.; Achour, S.; Avci, A.; Eskizeybek, V. Physical deposition of carbon doped titanium nitride film by DC magnetron sputtering for metallic implant coating use. Appl. Surf. Sci. 2014, 295, 81-85. [CrossRef]

107. Cicek, V. Corrosion Engineering; Tata McGraw-Hill Education: New York, NY, USA, 2014; ISBN 9781118720837.

108. Hua, L.; Hou, H. Electrochemical migration behaviors of lead-free 64Sn-35Bi-1Ag solder on FR-4 PCB board plated with Cu. Wuhan Univ. J. Nat. Sci. 2012, 17, 79-85. [CrossRef]

109. Mansour, S.F.; El-Dek, S.I.; Ahmed, M.K. Physico-mechanical and morphological features of zirconia substituted hydroxyapatite nano crystals. Sci. Rep. 2017, 7, 43202. [CrossRef]

110. Qin, L.Y.; Lian, J.S.; Jiang, Q. Effect of grain size on corrosion behavior of electrodeposited bulk nanocrystalline Ni. Trans. Nonferrous Met. Soc. China 2010, 20, 82-89. [CrossRef]

111. Escobar, C.A.; Caicedo, J.C.; A perador, W. Corrosion resistant surface for vanadium nitride and hafnium nitride layers as function of grain size. J. Phys. Chem. Solids 2014, 75, 23-30. [CrossRef]

112. Kinumoto, T.; Sou, Y.; Ono, K.; Matsuoka, M.; Arai, Y.; Tsumura, T.; Toyoda, M. Preparation of fibrous titania oxynitride-Carbon catalyst and oxygen reduction reaction analysis in both acidic and alkaline media. J. Power Sources 2015, 273, 136-141. [CrossRef]

(C) 2020 by the authors. Licensee MDPI, Basel, Switzerland. This article is an open access article distributed under the terms and conditions of the Creative Commons Attribution (CC BY) license (http://creativecommons.org/licenses/by/4.0/). 